\title{
Modeling of the variation of the electrical conductivity of the leachate of cocoa with different fermentation index
}

\section{(Modelización de la variación de la conductividad eléctrica del lixiviado de cacao con diferentes índices de fermentación)}

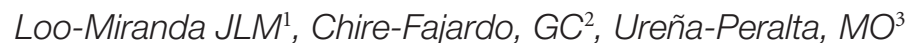

\begin{abstract}
This study linked the fermentation index of two varieties of cocoa beans: CCN 51 and ICS 6 with electrical conductivity (EC) of the water where they were immersed using a laboratory conductimeter. Mixtures of 11 fermented cocoa beans and unfermented were performed in order to obtain fermentation index from $0 \%$ (unfermented beans) to that reached by the fermented cocoa beans. Immersion times tested for determination of the electrical conductivity were 90 and 180 minutes. The results of electrical conductivity for CCN 51 and ICS 6 were $56.1 \pm 12.0$ to $1375.0 \pm 28.0$ $\mathrm{mS} / \mathrm{cm}$ and $150.0 \pm 19.9$ to $1199.3 \pm 44.5 \mathrm{mS} / \mathrm{cm}$, respectively. Subsequent conductivity values did not represent significant increases over time. The relationship between the fermentation index and electrical conductivity for CCN 51 showed positive trend, achieving a $\mathrm{R}^{2}=63.1 \%$. The following function by regression: $\mathrm{EC}\left(\mathrm{CCN}-5 \mathrm{I}_{\mathrm{I}}\right)=1196+10.83$ * $(\mathrm{FI})$ $-0.06 *(\mathrm{FI})^{2}$ got a model with significant adjustment to be used to determine its fermentation index.
\end{abstract}

\section{Keywords}

CCN 51, electrical properties, fermentation index, ICS 6, modeling.

\begin{abstract}
Resumen
El presente estudio relacionó el índice de fermentación de dos variedades de granos de cacao: CCN 51 e ICS 6, con la conductividad eléctrica (CE) del agua donde estuvieron inmersos, utilizando un conductímetro de laboratorio. Para ello se realizaron 11 mezclas de granos de cacao fermentados y no fermentados, con el propósito de obtener indices de fermentación desde 0\% (grano sin fermentar) hasta el alcanzado por el grano de cacao fermentado. Los tiempos ensayados de inmersión para la determinación de la conductividad eléctrica fueron de 90 y 180 minutos. Los resultados de la conductividad eléctrica para CCN 51 e ICS 6 fueron de $56.1 \pm 12.0$ a $1375.0 \pm 28.0 \mu \mathrm{S} / \mathrm{cm}$, $y$ de $150.0 \pm 19.9$ a $1199.3 \pm 44.5 \mu \mathrm{S} / \mathrm{cm}$, respectivamente. Valores de conductividad posteriores no representaron incrementos significativos en el tiempo. La relación entre el índice de fermentación y la conductividad eléctrica para CCN 51, mostró tendencia positiva, y se obtuvo un $R^{2}=63.1 \%$. Con la función lograda por regresión: CE (CCN-5) $=1196+10.83 *($ IF $)-0.06 *(\text { IF })^{2}$, se obtuvo un modelo con ajuste significativo a ser utilizado para determinar su indice de fermentación.
\end{abstract}

\section{Palabras clave}

CCN 51, indice de fermentación, ICS 6, modelamiento, propiedades eléctricas.

\section{Introduction}

Cocoa beans (Theobroma cacao L., Sterculiaceae) represent the seed of the tropical cocoa tree, growing in a limited geographical zone, of approximately $10^{\circ}$ to the north and south of the Equator (in particular Central America, West Indian islands, South America, Africa), Caligiani et al. (2014). Raw cocoa beans are inedible because of their bitter and astringent flavor and unpalatable and unpleasant taste. In order to obtain its unique sensory characteristics it need 
to undergo subsequent treatments including fermentation, drying and roasting. Therefore, the process of cocoa bean fermentation plays a significant role in determining the composition and flavor of chocolate and other cocoa-based products and it hence lays at the basis of the entire chocolate-making process. (De Vuyst and Weckx, 2016; Wood and Lass, 2001). Cocoa beans fermentation is the first stage in cocoa processing and consists in a microbial fermentation of the pulp surrounding the beans. It is generally a spontaneous phenomenon, operated by a microbial succession of a wide range of yeast and of lactic-acid and acetic-acid bacteria, producing a wide range of metabolic end products, in particular alcohol and organic acids. During and after fermentation, internal autolitic enzymes are activated by microbial metabolites, such as acetic acid, starting the chemical reactions (proteolysis and breakdown of polysaccharides) that form the precursors of cocoa flavor (Schwan and Wheals, 2004).

Currently, the fermentation index of the cocoa bean is calculated from a qualitative analysis of a sample of 300 units, for which a cocoa guillotine is used that cuts longitudinally to each grain in order to observe its internal physical structure and to issue a judgment of value on the degree of fermentation (INACAL, 2016). A well-fermented cocoa bean is characterized by a light to dark brown coloration and by having internal stretch marks and clefts. As a result of the process there is a higher content of certain minerals (Afoakwa et al., 2011) which can drive electrical energy. This characteristic of the change in composition motivated the use of electrical conductivity as an explanatory variable of the fermentation index, generating a faster, less tedious and more objective method by measuring its electrical conductivity. This could be possible with the existence of a mathematical function that correlates the fermentation index with the electrical conductivity of the cocoa beans. Several authors have proposed methodologies to determine the level of fermentation of the cocoa beans as the application of proton NMR together with chemometrics (Caligiani et al., 2014); the use of FT NIRS and chemometrics (Teye et al., 2015); determination of ammonia content by NIRS (Hue et al., 2014); cocoa quality index (CQI) adapted from the soil quality index (Araujo et al., 2014); artificial neural network model based on color measurements (León-Roque et al., 2016) being these methods limited for cocoa-farmers in the cocoa centers. Therefore, the objective of the present study was to determine the mathematical relationship between cocoa beans fermentation index and the value of the electrical conductivity of the aqueous medium in which they are immersed using CCN 51 and ICS 6 cocoa beans.

\section{Methodology}

Cocoa bean samples.- CCN 51 and ICS 6 are described:

CCN 51 is a cocoa clone of Ecuadorian origin with a fat content of $59.6 \pm 0.45 \%$, where the content of unsaturated fatty acids is 34,6\% (oleic acid C:18:1 and linoleic acid C:18:2). The sensory profiles define a mild aroma of cocoa and acid, medium brown color, ripe fruit flavor, chocolate notes, sustained mean acidity, low nut notes (Perea et al., 2013).

ICS 6 is a cocoa clone from Trinidad. ICS 6 was selected by Pound (1931) from the following crosses: trinitario $x$ criollo hybrid. This clone is characterized by a fat content of $57.1 \pm 0.42 \%$ where $36.2 \%$ corresponding to unsaturated fatty acids (oleic acid C:18:1 and linoleic acid C:18:2). The sensory profile define a dry fruit aroma, intense fruity (plum) flavor that lasts, with an average acidity at the end of the tasting, notes of chocolate and bitter very pleasant (Perea et al., 2013).

For this study both cocoa bean samples, CCN 51 and ICS 6, were cultivated in Uchiza, Tocache, San Martín, Peru. 
Analysis methods.- Samples of fermented (F) and unfermented (UF) cocoa beans (CCN 51 and ICS 6) (Garcia, 2012), were analyzed with the following methods:

- Proximate analysis.- Moisture content, crude protein, crude fat and ash were determined following the procedures in AOAC (2016) methods 931.04, 970.22, 920.75a, 972.15 respectively. Total carbohydrate was determined by difference (Alvarez, 2007) and crude fiber was determined following the procedures in AOAC (2016) methods 930.20a and 962.09e.

- Cut test.- The cut test was performed using the method described by NTP - ISO 1114 (INACAL, 2016). A total of 300 beans were cut lengthwise through the middle in order to expose the maximum cut surface of the cotyledons. Both halves were examined in full daylight and placed in one of the following categories: purple, pale purple, brown, slaty, germinated and moldy.

- Fermentation index.- The fermentation index was determined according to the method described by APPCACAO(2012) and Gutierrez(2009). The value of the fermentation index was calculated using the ration of well-fermented (brown) beans with respect to the total of beans analyzed in the cut test.

- Sample mixing.- Nine samples of mixtures of cocoa beans were prepared with the following ratios: (F: UF) 1:9, 2:8, 3:7, 4:6, 5:5, 6:4, 7:3, 8:2 and 9:1 for each of the varieties under study, with the purpose of having fixed values of fermentation indices that added to the sample of 100\% of $F(10: 0)$ and the sample of 100\%UF (0:10). Therefore a total of 11 experimental units were used for research.

- Electrical conductivity - The value of the electrical conductivity was measured with a laboratory conductivity-meter (INOLAB $尺$ COND Level 2P) following the method of Viloria and Méndez-Natera (2011), Viloria and Méndez-Natera (2007), Cepero et al. (2005) and Oblitas (2004). Samples of $20 \mathrm{~g}$ of cocoa beans mixtures were cut in halves. The samples were immersed in $200 \mathrm{ml}$ of deionized water. To standardized the immersion time the electrical conductivity of three sample of cocoa bean mixtures (ratios 10:0, 5:5 and 0:10) were measured every 10 minutes for four hour. This ensure that the value of electrical conductivity does not change significantly in time. Mathematically, this mean that the electrical conductivity follows an asymptotic function. In other words, it ensures that the obtained electrical conductivity value is in an equilibrium system. Finally, the electrical conductivity of each sample were measure after the immersion time for each variety (CCN 51 and ICS 6).

Statistical design.- The procedure of the Method of Non-Significant Variation in Kinetics - NSVK (Rubio, 2004) was applied, where a randomized complete design (RCD) and a comparison test of means such as Tukey were used. For RCD $(p<0.05)$, the time factor of immersion of cocoa beans had 25 treatments with three replicates, defined by the measurement times of the electrical conductivity (10 minutes intervals for four hours).

\section{Results and discussions}

Table 1 shows the results obtained from the proximate analysis expressed on dry basis (d.b). For both varieties, the composition varies with fermentation, especially the fat content is increased for unfermented cocoa beans (Asep, et al., 2008). Caligiani et al. (2014) found that possibly, the composition of the cocoa bean is influenced more by fermentation than by other factors such 
as botanical or geographic. In the case of crude protein content there are conflicting results, Afoakwa et al. (2011) found that with fermentation, the crude protein content was reduced, while Aremu et al. (1995) reports an increase of crude proteins to the six-day of fermentation. In this research, it was observed that at six-day fermentation the crude protein content in the CCN 51 cocoa bean was increased and for the ICS 6 cocoa bean was decreased. The crude fat content decreased with fermentation in CCN 51 and ICS 6 cocoa beans. Afoakwa et al. (2011) reported a reduction in fat content from 55.2 to $53.4 \%$ after fermentation. There were not significant differences in ash content with fermentation for all the cocoa varieties. This behavior was observed by Aremu et al. (1995) who reported ash content values of 4.4 and $5.4 \%$ in unfermented and fermented cocoa beans respectively. Total carbohydrates content was no significantly different in unfermented than fermented cocoa beans. However, Afoakwa et al. (2013) reported an increase of $4.5 \%$ in the carbohydrate content of cocoa beans with fermentation. The crude fiber content increased with fermentation from 5.07 to $5.70 \%$ in CCN 51 cocoa beans However, Aremu et al. (1995) reported a significant reduction in crude fiber content from 5.9 to $3.3 \%$ with fermentation.

Table 1. Proximate analysis (\% dried base) for cocoa beans

\begin{tabular}{|l|c|c|c|c|}
\hline \multicolumn{1}{|c|}{$\begin{array}{c}\text { Composition } \\
(\%)\end{array}$} & UF & F & UF & F \\
\cline { 2 - 5 } & $49.84 \pm 0.12^{\mathrm{a}}$ & $47.06 \pm 0.01^{\mathrm{b}}$ & $50.84 \pm 0.22^{\mathrm{a}}$ & $47.39 \pm 0.05^{\mathrm{b}}$ \\
\hline Crude fat & $19.53 \pm 0.21^{\mathrm{a}}$ & $17.44 \pm 0.05^{\mathrm{b}}$ & $18.47 \pm 0.04^{\mathrm{a}}$ & $20.58 \pm 0.03^{\mathrm{b}}$ \\
\hline Crude protein & $3.35 \pm 0.01^{\mathrm{a}}$ & $3.26 \pm 0.03^{\mathrm{a}}$ & $3.49 \pm 0.01^{\mathrm{a}}$ & $3.36 \pm 0.01^{\mathrm{a}}$ \\
\hline Ash & $27.28 \pm 0.30^{\mathrm{a}}$ & $32.24 \pm 0.09^{\mathrm{a}}$ & $27.20 \pm 0.27^{\mathrm{a}}$ & $28.67 \pm 0.12^{\mathrm{a}}$ \\
\hline Total carbohydrates & $5.07 \pm 0.06^{\mathrm{a}}$ & $5.70 \pm 0.10^{\mathrm{b}}$ & $5.14 \pm 0.00^{\mathrm{a}}$ & $5.16 \pm 0.07^{\mathrm{a}}$ \\
\hline Crude fiber & &
\end{tabular}

$(\mathrm{a}, \mathrm{b})$ Different letters in each row for each clone indicate that have significant difference $(\mathrm{p} \leq 0.05)$

Table 2 shows the results of the cut test performed on the cocoa beans. It determined that the fermentation index for the underfermented cocoa (UF) was 0\%. On the other hand, for six-day fermented cocoa beans, the fermentation index of the CCN 51 cocoa bean was found to be $90 \%$ (1621.67 $\mu \mathrm{S} / \mathrm{cm})$ and ICS 6 cocoa bean was 87\% (1098.00 $\mu \mathrm{S} / \mathrm{cm})$. In particular, slate and purple cocoa beans contain a high level of epicatechins and sucrose, which decreases in fermented cocoa beans by the loss of polyphenols. During fermentation the free amino acids are released, in fact they are found in low concentrations in the slate cocoa beans and the oligopeptides in the purple and brown cocoa beans are increased (Caligiani et al., 2014; Caligiani et al. 2016). According to Hansen et al. (1998), Misnawi et al. (2003) and Chire et al. (2016), the polyphenol oxidase is a key importance in pigment degradation during cocoa bean fermentation (50\% and $6 \%$ of activity in first two days of fermentation). The increased intensity of brown color is attributed to the oxidation of polyphenols by the action of polyphenol oxidase and during drying, forms a darker brown color although the enzyme has only $2 \%$ residual activity. The fermentation index (FI) is based on the color changes in the cotyledons of the cocoa beans during fermentation (Del Boca, 1962 and Camu et al., 2008), considered well-fermented the brown color beans(Caligiani et al., 2016), FI determines its physical and chemical quality (Rivera et al., 2012). However, this test could be subjective and not very consistent, because the human error increases with the fatigue making its results variable and not consistent at all (Llangantileke et al., 1991). 
Table 2. Determination of fermentation index (IF)

\begin{tabular}{|c|c|c|c|c|c|c|}
\hline \multirow[t]{2}{*}{ Cocoa bean } & \multirow[t]{2}{*}{ Sample } & \multirow{2}{*}{$\begin{array}{l}\text { Fermented } \\
\text { cocoa beans }\end{array}$} & \multicolumn{2}{|c|}{$\begin{array}{l}\text { Unfermented } \\
\text { cocoa beans }\end{array}$} & \multirow[t]{2}{*}{ Moldy } & \multirow[t]{2}{*}{ FI (\%) } \\
\hline & & & Slate & Purple & & \\
\hline CCN 51 & UF & 0 & 286 & 14 & 0 & 0 \\
\hline CCN 51 & $\mathrm{~F}$ & 270 & 0 & 29 & 1 & 90 \\
\hline ICS 6 & UF & 0 & 279 & 21 & 0 & 0 \\
\hline ICS 6 & $\mathrm{~F}$ & 260 & 0 & 40 & 0 & 87 \\
\hline
\end{tabular}

The variation of the values of electrical conductivity as a function of the immersion time was recorded. The lowest immersion time values were found in the samples of unfermented (0:10) and fermented (10:0) cocoa beans (CCN 51 and ICS 6). However, the highest immersion time corresponding to 5:5 mixtures in the CCN 51 and ICS 6 cocoa beans, obtained at 180 and 90 minutes of immersion, respectively; times from which there were no significant differences $(p<0.05)$ between subsequent values. It should be noted that both measurement times were obtained by applying the method of Non-Significant Variation in Kinetics (NSVK), it means, from these values no significant differences $(p<0.05)$ were found in the posterior values.

Figure 1 show the variation of the electrical conductivity of CCN 51 and ICS 6 with a fermentation index of $45 \%$ and $43.5 \%$ respectively. The electrical conductivity values for CCN 51 increased from $56.1 \pm 12.0$ to $1375.3 \pm 28.0 \mu \mathrm{S} / \mathrm{cm}$ and for ICS 6 increased from $150.0 \pm 19.9$ to $1199.3 \pm 44.5 \mu \mathrm{S} / \mathrm{cm}$. Therefore, the time of immersion of CCN 51 and ICS 6 were 180 and 90 minutes respectively, subsequent values did not represent significant increases over time.

Figure 1. Variation of the electrical conductivity $(\mu \mathrm{S} / \mathrm{cm}$ ) of a $5: 5$ blend for the (a) CCN $51(45 \% \mathrm{FI})$ and (b) ICS $6(43.5 \%$ FI) cocoa beans. Different letters show significant difference at $p \leq 0.05$
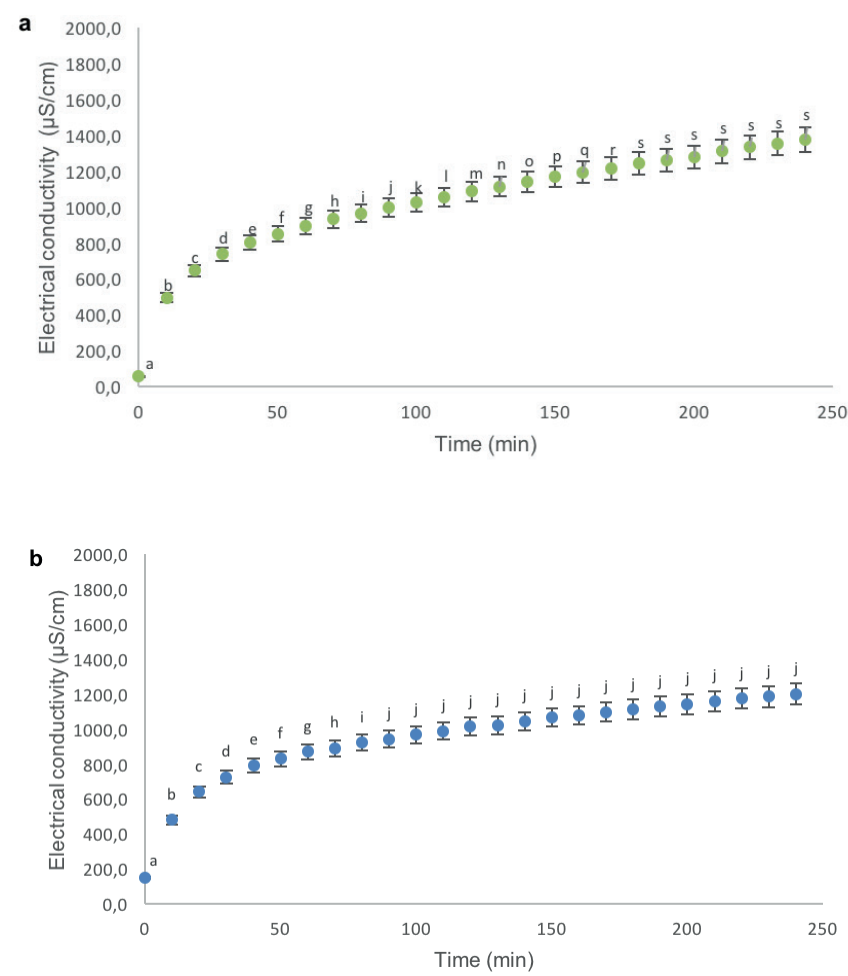
The electrical conductivity of the 11 mixtures were measure (by triplicate) taking into consideration the appropriate immersion time of 90 (CCN 51) and 180 (ICS 6) minutes. Figure 2 and 3 show the relationship between electrical conductivity and fermentation index of the 11 mixtures of CCN 51 and ICS 6 cocoa beans. The mathematical models that adjusted the experimental values by variety were the following:

$$
\begin{aligned}
& \operatorname{EC~}\left({ }_{\text {CCN 51 }}\right)=1196+10.83 *(\mathrm{FI})-0.06 *(\mathrm{FI})^{2} \\
& \operatorname{EC~}\left(_{\text {ICS } 6.3}\right)=1088+3.90 *(\mathrm{FI})-0.05 *(\mathrm{FI})^{2}
\end{aligned}
$$

Coefficient of determination of CCN 51 cocoa bean model was $\mathrm{R}^{2}=63.1 \%$, with $p$-value $\leq$ 0.05. In the case of the ICS 6 cocoa bean model the coefficient of determination was $R^{2}=18.6 \%$ ( $p$-value $\leq 0.05)$. $R^{2}$ is used to analyze how differences in one variable can be explained by a difference in a second variable (Triola, 2009). This means that 63.1 and $18.6 \%$ of the variance in electrical conductivity is due to the fermentation index of CCN 51 and ICS 6 respectively. Colosimo and Galetti (2012) tried to find a relation between the content of ashes and color with electric conductivity of 19 single-flowered lotus and eucalyptus honey. Only the color coefficient was statistically significant $(p \leq 0.05)$ to predict the values of conductivity. The coefficient of determination of color with the electrical conductivity was equal to $\mathrm{R}^{2}=0.74$.

Figure 2. Electrical conductivity $(\mu \mathrm{S} / \mathrm{cm})$ with respect to the fermentation index of CCN 51 cocoa beans

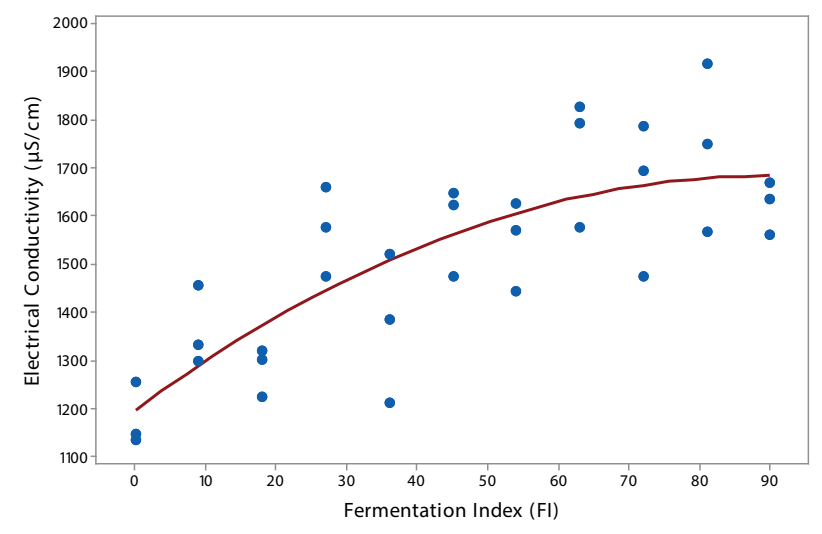

Figure 3. Electrical conductivity $(\mu \mathrm{S} / \mathrm{cm})$ with respect to the fermentation index of ICS 6 cocoa beans

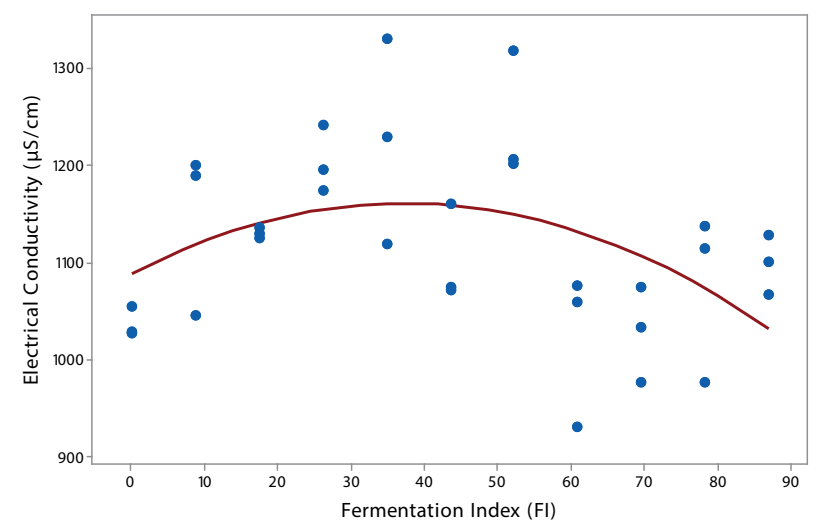


Lamsal and Jindal (2014), evaluated the electrical conductivity in orange, pineapple and tomato juice determining that it was influenced by the maturity of the fruit, and culture conditions, reporting that there was no high proportional relationship between the variables evaluated, stating that the fruits of the different localities showed a variation of $10 \%$ of the average of the value, as well as, the average values of electrical conductivity for pineapple and tomato juice with maximum variations due to the locality of 20 and $18.3 \%$ respectively. To summarize there are different variables than influence in the electrical conductivity. In this study, it should be noted that there are differences between varieties of cocoa beans. In this case, for ICS 6, it is recommended to carry out a larger number of tests, physical properties studies, as well as to know in depth its composition, with the purpose of knowing the cause of the reduction of the electrical conductivity to higher rate of fermentation.

\section{Conclusions and recomendations}

The study found that there is a relationship between the fermentation index of cocoa beans and the electrical conductivity of the deionized water containing them. It was also determined that the appropriate immersion time with stirring in deionized water was 180 minutes to measure conductivity in the horizontal part of the curve. The mathematical model that adjusts the experimental values was explained by a quadratic model: EC $\left({ }_{\mathrm{CCN} 51}\right)=1196+10.83$ * $(\mathrm{FI})-0.06$ * $(\mathrm{FI})^{2}$ with $\mathrm{R}^{2}=63.1 \%$ and $p$-value $\leq 0.05$ for CCN51. Cocoa companies and chocolate factories can use this model to judge the quality of the CCN 51 cocoa bean using a conductivity-meter. However, for other varieties like ICS 6 further studies are required to find closer mathematical relationships.

Acknowledgments: To research management office (RMO) at Universidad Nacional Agraria La Molina (UNALM), for support funds for this research.

\section{References}

Afoakwa, E.; Quao, J.; Takrama, J. et al. (2011). Effect of Pulp Preconditioning On Acidification, Proteolysis, Sugars and Free Fatty Acids Concentration during Fermentation of Cocoa (Theobroma cacao) Beans. International Journal of Food Sciences and Nutrition, 62(7), 755-764.

Afoakwa, E.; Quao, J.; Takrama, J., et al. (2013). Chemical Composition and Physical Quality Characteristics of Ghanaian Cocoa Beans as Affected by Pulp Pre-Conditioning and Fermentation. Journal of Food and Science Technology, 50(6), 1097-1105.

Álvarez, C., Pérez, E., Lares, M.C. (2007). Caracterización física y química de las almendras de cacao fermentadas, secas y tostadas cultivadas en la región de Cuyagua, Estado de Aragua. Agronomía Tropical, 57(4), 249-256.

AOAC. (2016). Official Methods of Analysis of AOAC International. Method 931.04, 970.22, 920.75a, 972.15, 930.20a, 962.09e. (20. ${ }^{\circ}$ ed.), Vol. II. William Horwitz and George W. Latimer, Jr. (Eds.) Maryland, USA.

APPCACAO. (2012). Manual de control de calidad del cacao. Perú.

Araujo, Q. R.; Cinira, A, E.; Fernandes, C. A., et al. (2014). Cocoa Quality Index-A proposal. Food Control, 46, 49-54.

Aremu, C. Y.; Agiang, M. A.; Ayatse, J. O. (1995). Nutrient and Antinutrient Profiles of Raw and Fermented Cocoa Beans. Plant Foods Human Nutrition, 48, 221-223.

Camu, N.; De Winter, T.; Addo, S. K., et al. (2008). Fermentation of Cocoa Beans: Influence of Microbial Activities and Polyphenol Concentrations on the Flavour of Chocolate. Journal of the Science of Food and Agriculture, 88, 2288-2297.

Caligiani, A.; Palla, L.; Acquotti, D., et al. (2014). Application of H NMR for the Characterization of Cocoa Beans of Different Geographical Origins and Fermentation Levels. Food Chemistry, 157, 94-99. 
Caligiani, A.; Marseglia, A.; Prandi, B., et al. (2016). Influence of Fermentation Level and Geographical Origin on Cocoa Bean Oligopeptide Pattern. Food Chemistry, 211, 431-439.

Cepero, O.; Camacho, C.; Castillo, J. C., Salado, J. (2005). Conductividad eléctrica y california mastitis test en la detección de la mastitis subclinicas. Revista electrónica de veterinaria Redvet, VI, 3.

Colosimo, J.; Galetti, V. (2012). Evaluación de la conductividad eléctrica y otros parámetros fisicoquímicos en mieles monoflorales de lotus y eucalipto. Memorias de la 5ta Jornada de Eficiencia y Tecnología, 1-6.

Chire, G. C.; Verona, P.; Guzman, J. (2016). Cambios en el color durante el beneficio del grano de cacao (Theobroma cacao L.) peruano procedente de Piura. Ciencia e investigación, 19(1):29-34.

Del Boca, C. (1962). Cocoa Beans: Quality Requirements and Methods of Assessment. Rev Int Chocolaterie, 17, 218-221.

De Vuyst, L.; Weckx, S. (2016). The Cocoa Bean Fermentation Process: From Ecosystem Analysis to Starter Culture Development. Journal of Applied Microbiology, 121, 5 - 17.

García, L. F. (2012). Catálogo de cultivares de cacao del Perú. Ministerio de Agricultura. 1era Re-impresión.

Gutiérrez, M. (2009). Guía de gestión de la calidad en centro de acopio, secado y fermentación de cacao. Perú: Dirección de Promoción y Competitividad. Ministerio de Agricultura..

Hansen, C. E.; Del Olmo, M.; Burri, C. (1998). Enzyme Activities in Cocoa Beans During Fermentation. J. Sci. Food Agric., 77, 273-281.

Hue, C.; Gunata, Z:; Bergounhou, A., et al. (2014). Near Infrared Spectroscopy as a New Tool to Determine Cocoa Fermentation Levels through Ammonia Nitrogen Quantification. Food Chemistry, 148, 240-245.

Ilangantileke, S. G.; Wahyudi, T.; Bailon, M. G. (1991). Assessment Methodology to Predict Quality of Cocoa Beans for Export. Journal of Food Quality, 14(6), 481-496.

Inacal (2016). NTP - ISO 1114. Granos de cacao. Prueba de corte. 4ta Edición. Lima, Perú, p.1-2.

Lamsal, B. P.; Jindal, V. K. (2014). Variation in Electrical Conductivity of Selected Fruit Juices During Continiuos Ohmic Heating. International Journal of Applied Science and Technology, 7(1), 47-56.

León-Roque, N.; Abderrahim, M.; Nuñez-Alejos, L., et al. (2016). Prediction of Fermentation Index of Cocoa Beans (Theobroma cacao L.) Based on Color Measurement and Artificial Neural Networks. Talanta, 161, 31-39.

Misnawi; Jinap, S.; Jamilah, B.; Nazamid, S. (2003). Effects of Incubation and Polyphenol Oxidase Enrichment in Color, Fermentation Index, Procyanidins and Astringency of Unfermented and Partly Fermented Cocoa Beans. International Journal of Food Science and Technology, 38, 285-295.

Oblitas, F. A.; Barrantes, F. A.; Amorós, C. (2004). Valores de referencia de conductividad eléctrica y su relación con la concentración de cloruros en leches normales de bovinos de la campiña Cajamarca. Revista Caxamarca, 12(1), 87-92.

Perea, A.; Martínez, N.; Aranzazu, F.; Cadena, T. (2013). Características de calidad del cacao de Colombia. Catálogo de 26 cultivares. Universidad Nacional de Santander, Federación Nacional de Cacaoteros. Bucaramanga.

Rivera, R.; Mecías, F.; Guzmán, A., et al- (2012). Efecto del tipo y tiempo de fermentación en la calidad física y química del cacao (Theobroma cacao L.) tipo nacional. Revista ciencia y tecnología, 5(1), 7-12.

Rubio, E. (2004). Determinación del tiempo óptimo de homogenización de partículas en un mezclador de volteo tipo pantalón. Tesis para optar el título de Ingeniero en Industrias Alimentarias. Lima: Universidad Nacional Agraria La Molina.

Schwan, R. F.; Wheals, A. E. (2004). The Microbiology of Cocoa Fermentation and its Role in Chocolate Quality. Critical Reviews in Food Science and Nutrition, 44, 205-221.

Teye, E.; Huang, X.; Sam-Amoah, L. K., et al. (2015). Estimating Cocoa Bean Parameters by FT-NIRS and Chemometrics Analysis. Food Chemistry, 46, 403-410.

Triola, M. F. (2009). Estadística. (10. ed.). México D. F.: Pearson Education.. 904.

Viloria, H.; Méndez Natera, J. R. (2011). Relación entre la conductividad eléctrica, pH del agua de remojo, germinación de semillas y crecimiento de plántulas de maíz (Zea mayz L.) bajo dos condiciones experimentales. Scientia agropecuaria, 2, 213-228. 
Viloria, H.; Méndez Natera, J. R. (2007). Determinación del periodo de remojo adecuado para las mediciones de pH y conductividad eléctrica en semillas de maíz (Zea mayz). Boletín del Centro de Investigaciones Biológicas, 41(2), 227-243.

Wood, G.; Lass, R. A. (2001). Cocoa. Oxford; Fourth Ed. Blackwell Science. 